\title{
Cancer-Derived Exosomes as Effectors of Key Inflammation-Related Players
}

\author{
Norahayu Othman, Rahman Jamal and Nadiah Abu* \\ UKM Medical Centre, UKM Medical Molecular Biology Institute, Kuala Lumpur, Malaysia
}

Exosomes, a category of small lipid bilayer extracellular vesicles that are naturally secreted by many cells (both healthy and diseased), carry cargo made up of proteins, lipids, DNAs, and RNAs; all of which are functional when transferred to their recipient cells. Numerous studies have demonstrated the powerful role that exosomes play in the mediation of cell-to-cell communication to induce a pro-tumoral environment to encourage tumor progression and survival. Recently, considerable interest has developed in regard to the role that exosomes play in immunity; with studies demonstrating the ability of exosomes to either metabolically alter immune players such as dendritic cells, T cells, macrophages, and natural killer cells. In this review, we summarize the recent literature on the function of exosomes in regulating a key

OPEN ACCESS

Edited by:

Fatemeh Momen-Heravi, Columbia University, United States

Reviewed by:

Mallikarjun Bidarimath, Cornell University, United States

Kawaljit Kaur,

University of California, Los Angeles, United States

${ }^{*}$ Correspondence: Nadiah Abu

nadiah.abu@ppukm.ukm.edu.my

Specialty section:

This article was submitted to Cancer Immunity and Immunotherapy, a section of the journal

Frontiers in Immunology

Received: 25 May 2019

Accepted: 20 August 2019

Published: 04 September 2019

Citation:

Othman N, Jamal R and Abu N (2019)

Cancer-Derived Exosomes as

Effectors of Key Inflammation-Related

Players. Front. Immunol. 10:2103.

doi: 10.3389/fimmu.2019.02103 process that has long been associated with the progression of cancer-inflammation and immunity.

Keywords: Exosomes, cancer, inflammation, immune molecules, tumorigenesis

\section{INTRODUCTION}

\section{Inflammation and Cancer}

The inflammatory response is a mechanism that is activated in response to tissue damage or recognition of pathogens, and is facilitated by the action of various cells and soluble mediators of the innate and adaptive immune system $(1,2)$. In the normal physiological context, once the homeostatic state has been achieved, through the elimination of the foreign pathogen or successful tissue repair, inflammation will be resolved (3). However, if inflammation becomes unregulated and is inadequately resolved it can result in chronic inflammation, which has been linked with an increase in the risk of malignant cell transformation and cancer $(2,4)$.

The inflammatory and the carcinogenic process share several molecular targets and signaling pathways including apoptosis, proliferation, and angiogenesis. Therefore, sustained exposure to the inflammatory process can contribute to the initiation, promotion, growth, and invasion of tumors by providing bioactive inflammation-related molecules to cells that can infiltrate the tumor microenvironment $(1,2)$. These molecules include integral players of cancer-related inflammation such as transcription factors $\mathrm{NF} \kappa \mathrm{B}$ and signal transducer activator of transcription 3 (Stat3), as well as primary inflammatory cytokines such as interleukin (IL)-1 $\beta$, IL-6, and tumor necrosis factor alpha (TNF- $\alpha$ ) (5-8). Accumulation of these inflammatory mediators leads to local and systemic immunosuppression associated with the progression of cancer. Furthermore, several reports have provided accumulating evidence that inflammatory factors are able to down-regulate DNA repair pathways and cell cycle checkpoints, which results in the buildup of random genetic alterations due to the destabilization of the cancer cell genome $(9,10)$. Additionally, cytokines such as TNF- $\alpha$ and 
IL- 6 have also been reported to induce the production of free radicals leading to DNA damage and mutations that can further contribute to the initiation of tumors $(11,12)$.

While inflammation plays a significant role in the promotion of tumor progression, the recruitment of inflammatory cells and up-regulation of anti-inflammatory cytokines by the host is also aimed at suppressing tumor growth. For example, classically activated M1 macrophages exhibit anti-tumor activity and elicit anti-tumor adaptive immunity in the early stages of carcinogenesis (13), by damaging vascular cells and activating coagulation to induce hemorrhagic necrosis (14). However, in established and advanced neoplasia M2-polarized macrophages outweigh M1 macrophages and tumor cells will escape immune attack (13). The balance between the anti-tumor and pro-tumor properties of macrophages is demonstrated to be regulated by $\mathrm{NF}-\kappa \mathrm{B}$, thus NF- $\kappa \mathrm{B}$ can be targeted to favor the anti-tumor macrophage function $(15,16)$.

\section{Cancer-Derived Exosomes}

Exosomes are a category of small lipid bilayer extracellular vesicles that measures approximately $30-100 \mathrm{~nm}$ (17-19). The process of exosomes biogenesis (Figure 1) begins with invagination of the plasma membrane to form endosomes. As the endosomes mature, inward budding of the endosome membrane will result in the formation of numerous intraluminal vesicles (ILV) that contain components of the cytosol, including nucleic acids and functional proteins (18, 20-24). The late endosome, now termed multivesicular bodies (MVB), will fuse with the plasma membrane to release the ILVs into the extracellular space, exosomes (25). Exosomes play an integral role in intercellular communication and act as shuttles by transmitting signals and transferring of their contents, thus playing a role in the regulation of physiological and pathological processes of diseases (26-28). The cargo of exosomes is made up of proteins, lipids, DNAs (mtDNA, ssDNA, dsDNA), and RNAs (mRNA, miRNA, long non-coding RNA), which are all functional when transferred into recipient cells (29-32). Exosomes are released from most cell types and can be found in all bodily fluids including urine, plasma, saliva, cerebrospinal fluid, amniotic fluid, and breast milk (33-36).

Extensive reports have illustrated that exosomes derived from tumors are significantly involved in the modulation of the biological activities of their recipient cells via the transfer of their oncogenic content. For example, exosomes play a role in the induction of normal cell transformation. A study has demonstrated that prostate cancer cell-derived exosomes are involved in the clonal expansion of tumors through reprogramming of adipose-derived stem cells via trafficking of oncogenic factors such as H-ras and K-ras transcripts, as well as oncogenic miRNAs miR-125b, miR-130b, and miR-155 (37). Breast cancer cell-derived exosomes have also been shown to promote normal cell transformation. It was determined that exosomes derived from cells and sera of breast cancer patients was able to promote the formation of tumors from nontumorigenic epithelial cells in a Dicer-dependent manner (38). Other biological activities affected by tumor-derived exosomes include cell proliferation; as observed in colon cancer cells whereby a transfer of exosomes from colon tumor cells was able to induce a rise in cell proliferation and chemoresistance in acceptor cells both in vitro and in vivo (39). Up-regulation of angiogenesis has also been detected to be influenced by tumor-derived exosomes. One study demonstrated that leukemia cells-derived exosomes was able to transport miRNAs (miR92a) to endothelial cells to modulate endothelial migration and tube formation (40). The metastatic ability of cells can also be modulated by tumor derived-exosomes. Exosomes isolated from melanoma cells of stage $\mathrm{V}$ patients is able to stimulate the formation of a metastatic niche by encouraging bone marrow-derived cells toward a pro-metastatic phenotype via upregulation of the MET oncoprotein (41). Furthermore, there is potential for the development of exosomes as diagnostics biomarkers as they contain all the bioactive molecules of the cells they are derived from (42-46).

Recently considerable interest has developed in regard to the role that exosomes play in the immune response, with studies demonstrating the ability of exosomes to either promote or inhibit immune responses. For example, exosomes derived from thrombin-activated platelets are able to stimulate the proliferation, survival, and chemotaxis of hematopoietic cells (47) as well as activate monocytes to release pro-inflammatory cytokines and induce the activation of B cells (48). Furthermore, exosomes released by antigen presenting cells such as Blymphocytes and dendritic cells contain MHC class I molecules that are able to potentially mediate antigen-specific T cell crosspriming (49-53). Natural killer (NK) cells-derived exosomes have also been shown to mediate anti-tumor activities via its cellular content perforin and granzyme B, which has cytotoxic activity against various tumor cell lines (54). It has also been reported that peptides expressed in exosomes derived from mast cells can be presented to dendritic cells to stimulate specific immune responses (55). Various immune suppressive roles of exosomes include the promotion of apoptosis in activated $\mathrm{T}$ cells via expression of death ligands FasL (56) and TRAIL (57); impairment of dendritic cell differentiation from monocytes (58); as well as the suppression of NK cells mediated cytotoxic responses (59).

\section{PRO-INFLAMMATORY EFFECTS OF EXOSOMES}

\section{Monocytes}

Monocytes are a subset of mononuclear leukocytes, or circulating white blood cells, which differentiates into macrophages and dendritic cells following stimulation by cytokines and other molecules $(60,61)$. Monocytes play a significant role in both innate and adaptive immunity (62) through the production of various effector molecules such as inflammatory cytokines, myeloperoxidase, and superoxide, to contribute toward and initiate local and systemic inflammation $(63,64)$. During chronic inflammation, cytokines have been reported to promote the creation of ideal growth conditions within the tumor microenvironment as well as to promote the progression of tumor growth (65-67). Tumor cells and its 

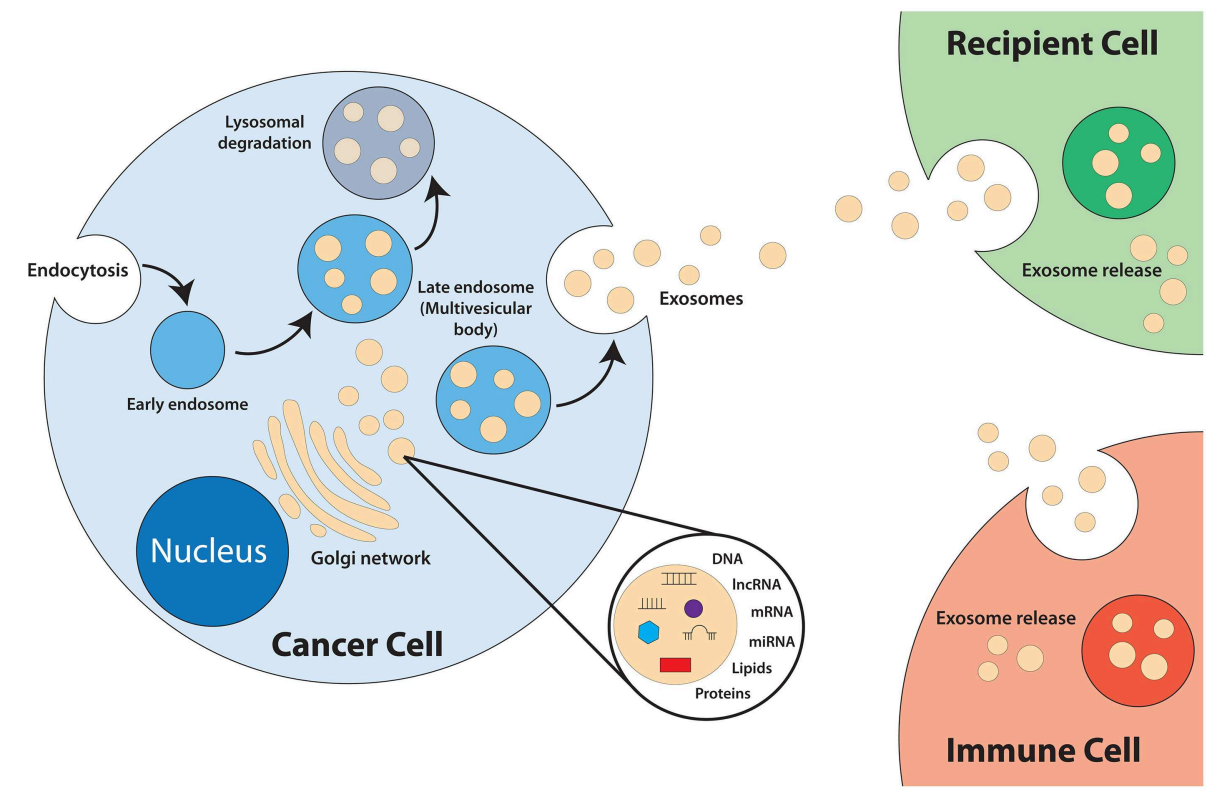

FIGURE 1 | Biogenesis of exosomes.

associated microenvironment can produce molecules that alter the recruitment, migration, differentiation, and functional properties of monocytes (68).

Exosomes produced and released by tumor cells contain various biomolecules that can be transmitted to recipient cells, including monocytes, to regulate their behavior. In a study conducted in 2013 by Bretz et al. it was demonstrated that exosomes obtained from malignant ascites of ovarian cancer patients were able to modulate the biological functions of monocytic cells (69). Results indicated that tumor-derived exosomes were transferred into the THP-1 human monocytic cells and significantly induced the production and secretion of various pro-inflammatory cytokines including interleukin (IL)6 , IL-1 $\beta$, and IL-8, and tumor necrosis factor (TNF)- $\alpha$, via TLR2 and TLR4 binding on the cell surface of monocytes, which subsequently activated nuclear factor $\kappa \mathrm{B}(\mathrm{NF} \kappa \mathrm{B})$ and signal transducer and activator of transcription 3 (STAT3) (69). NF- $\mathrm{B}$ is a significant regulator of inflammation, and constitutive activation of $\mathrm{NF \kappa B}$ is often observed in cancer cells and is associated with an aggressive phenotype, which includes tissue invasion and metastasis as well as resistance to growth inhibition (70). NF- $\kappa \mathrm{B}$ is activated downstream of the TLR-MyD88 pathway and inflammatory cytokines TNF- $\alpha$ and IL-1 $\beta$ (9). Furthermore it has recently been shown that STAT3 is required for the activation of NFKB and interaction between these two transcription factors is essential for the regulation of communication between inflammatory and cancer cells. Together, NFКB and STAT3 have the capability to regulate apoptosis, angiogenesis, and tumor invasion thus enabling resistance toward immune surveillance $(1,71)$.

The role of tumor-derived exosomes in the cross-talk with monocytes was also evaluated in a separate study focused on chronic lymphocytic leukemia (CLL). CLL-derived exosomes was found to play a role in the skewing of monocytes and macrophages toward a pro-tumorigenic phenotype with the release of tumor-supportive cytokines as well as the expression of immunosuppressive molecules such as programed cell death 1 ligand (PD-L1). Furthermore, the authors discovered that noncoding Y RNA hY4 transcript was enriched in CLL-derived exosomes and acts as a ligand to facilitate the significant increase in secretion of CCL2, CCL3, CCL4, CXCL10, and IL-6 via TLR7 signaling (72).

\section{Macrophages}

Macrophages immune cells that have important roles in antigen presentation, phagocytosis, and immunomodulation $(73,74)$ and their functional phenotypes are extremely versatile and dependent upon the tissue type and signals presented within it's microenvironment, thus allowing macrophages to play multiple roles in the inflammatory process (74-76). Activation of M1phenotype macrophages leads to immunostimulation, with an increase in production of pro-inflammatory cytokines and chemokines leading to the effective elimination of pathogens and infection $(77,78)$, while the M2 macrophages are antiinflammatory and promote progression of tumors, stimulate angiogenesis and wound healing $(78,79)$. Various studies have reported the mechanisms by which intercellular communication between cancer cells and tumor-associated macrophages, via exosomes, can regulate the function and phenotype of these immune cells.

Breast (80) and gastric (81) tumor-derived exosomes can induce a M1 pro-inflammatory response in macrophages through the activation of $\mathrm{NF} \mathrm{B}$, which in turn stimulates production of inflammatory cytokines including GCSF, IL-6, IL8 , IL-1 $\beta$, CCL2, and TNF- $\alpha$. Chow et al. in 2014 further revealed that the activation of $\mathrm{NF \kappa B}$ is mediated by the interaction 
between breast cancer-derived exosomes and macrophages, and is largely influenced by the presence of TLR2 and palmitoylated protein ligands on the surface of macrophages and tumorderived exosomes, respectively (80). In another study, NFкB in macrophages was activated through binding of miR-21 and miR-29a, secreted by tumor-derived exosomes, to murine TLR7 and human TLR8, to trigger a TLR-mediated prometastatic inflammatory response to promote tumor growth and metastasis (82).

Annexin A2, which is highly expressed in breast-cancer derived exosomes, has also been reported to play a role in macrophage-mediated inflammatory response (83). Annexin A2 mediates M1 macrophage activation of p38MAPK, NFkB, and STAT3 pathways by increasing the secretion of IL- 6 and TNF$\alpha$. Furthermore, priming of animals with breast cancer-derived exosomes containing high annexin A2, led to an increased level of VEGFR1 in lung and brain sections, with a concordant increase in MMP9 in tissues. Up-regulation of VEGFR1 and MMP9 expression by tumor-derived exosomes was linked with breast cancer metastasis and extracellular proteolysis and angiogenesis, respectively (83).

\section{Dendritic Cells}

Dendritic cells are professional antigen-presenting cells (APCs) that functions to recognize, process, and present antigens to $\mathrm{T}$ cells of the immune system via major histocompatibility complex (MHC) molecules, along with co-stimulatory molecules and cytokines to initiate the immune system (84). Tumorderived exosomes have been reported to be potent immune suppressors via inhibition of dendritic cell differentiation. Results from a study conducted by $\mathrm{Yu}$ et al. in 2007 demonstrated that administration of exosomes caused an accumulation of undifferentiated myeloid precursor cells in the spleen of mice, and in vitro introduction of exosomes to myeloid precursor cells resulted in the blockage of differentiation. This inhibition of dendritic cell differentiation is mediated through the induction of IL- 6 by tumor-derived exosomes (85). In another study, tumor-derived exosomes was able to inhibit the differentiation of human monocyte precursors into dendritic cells in melanoma and colorectal cancers. Additionally, these monocytes gained the ability to secrete TGF $\beta$ further inhibiting the proliferation of T lymphocytes (86). Recently a study has determined that tumorderived exosomes (TEX)-activated dendritic cells (Ta-TEXs) are able to increase the production of inflammatory mediators of dendritic cells, which include IL-6 and prostaglandin E1 (PGE1). The binding of a natural ligand, Hsp105, found on the surface membrane of tumor-derived exosomes to TLR2 and TLR4, stimulates the secretion of IL-6 and PGE1. This in turn leads to an increase in tumor cell invasion and metastasis via phosphorylation of STAT3, which in turn promotes the transcription of matrix metallopeptidase 9 (MMP9) by binding to the MMP9 promoter (87). Furthermore, pancreatic cancerderived exosomes have been reported to down-regulate the expression of TLR4 expression in dendritic cells, via the transfer of miR-203. This led to a subsequent decrease in expression of TNF- $\alpha$ and IL-12 (88).

\section{Myeloid Derived Suppressor Cells (MDSC)}

Myeloid derived suppressor cells (MDSCs) are a heterogeneous population of immature myeloid cells comprised of precursors of dendritic cells, macrophages, and granulocytes. The accumulation of MDSCs in tumor-bearing mice (89) and humans $(90,91)$ have been widely reported, and mounting evidence has indicated that the tumor microenvironment produces various factors that inhibit the maturation and differentiation of these immunoregulatory cells (92-94). The accumulation of MDSCs has been shown to play a role in the promotion of tumor progression, by suppressing antigen processing and presentation as well as $\mathrm{T}$ cell activation, which consequently inhibits immune surveillance and anti-tumor immunity (95-97).

Tumor-derived exosomes have the ability to induce the accumulation of MDSCs in tumors. Yu et al. reported that tumorderived exosomes can be taken up by bone marrow precursor cells and induce a switch in the differentiation pathway of these myeloid cells to the MDSC pathway (85). The tumor microenvironment then increases the recruitment of immune suppression molecules PGE2 and TGF- $\beta$, into the exosomes, which then facilitates tumor growth through the induction of pro-inflammatory cytokine Cox 2. These tumor exosomes were also found to release pro-inflammatory cytokines IL-6 and tumor growth factor VEGF further enhancing its role in tumor growth (98). Exosome Hsp70 (99) and Hsp72 (100) have both been reported to expand and induce the activation of MDSCs. When treated with exosomal Hsp70 and Hsp72, MDSCs was found to significantly increase the production of pro-inflammatory cytokines including IL-6, TNF- $\alpha$, VEGF, and CCL2, leading to an increase in tumor growth and metastasis (100). In accordance with these changes in phenotype, exosomal Hsp70 was also found to trigger phosphorylation of STAT3 in a TLR2-MyD88dependent manner (101).

MyD88 is a key cytoplasmic adaptor protein required for the integration and transduction of signals generated by the TLR family (101). Recent reports have determined that MyD88 plays a critical role in the inhibition of myeloid cell differentiation into dendritic cells. Results from a study conducted by Liu et al., found that melanoma exosomes have no inhibitory effect on the differentiation of bone marrow (BM) precursor cells isolated from MyD88 knockout mice, whereas an inhibitory effect was observed with BM precursor cells isolated from wildtype mice. Furthermore, significant reduction was observed in the percentage of dendritic cells in wild-type mice exposed to melanoma exosomes, while no significant effects was observed in MyD88 knockout mice (101). This indicates that MyD88 plays a crucial role to the induction of MDSCs.

Furthermore, exosomes derived from MDSCs have been reported to promote tumor progression by facilitating the polarization of M1 macrophages with a tumoricidal phenotype, to a tumor-promoting M2 macrophage, via inhibition of macrophage production of IL-2 production (102).

\section{Others}

As previously described, communication between cancer cells and their microenvironment can be mediated via exosomes 
through the transfer of their cargo which includes proteins, DNAs, messenger RNAs and microRNAs (103-105). For example, exosomes originating from arsenite-transformed hepatic epithelial cells, L- 02 cells, can induce a pro-inflammatory reaction in normal liver cells by transferring exosomal miR-155 (106). Briefly, in response to arsenite exposure, NFKB will be activated to promote the overexpression of miR-155, which in turn will be transferred to normal liver cells via exosomes to influence the production of IL-6 and IL- 8 to evoke a proinflammatory response via STAT3 (106-108). Exosomes have also been reported to secrete proteins to initiate an inflammatory response. A study has described the release of an enzyme known to be essential for protein synthesis, lysyl-tRNA synthetase (KRS), from exosomes derived from colorectal carcinoma cells (109). Caspase 8 was found to facilitate the secretion of KRS from exosomes, which in turn induced the release of cytokines and factors that are known markers for M1 and M2 macrophages, including TNF- $\alpha, \mathrm{C}-\mathrm{X}-\mathrm{C}$ motif chemokine ligand 10 (CRG2), IL-6 and MMP9 (109). Heat shock protein, crystallin alpha B (CRYAB) has also been described to be released from glioblastoma multiforme (GBM) derived-exosomes in response to exposure to pro-inflammatory cytokines IL- $1 \beta$ and TNF- $\alpha$, to exert an anti-apoptotic activity (110). Furthermore, results indicated that following an increase in cytokine levels in GBM cells, due to either radiation or disease, significant changes occur in the GBM derived-exosomal proteome which may promote progression of inflammation, tumor invasiveness, angiogenesis, and tumor progression (110).

\section{ANTI-INFLAMMATORY EFFECTS OF EXOSOMES}

Tumor inflammation plays a crucial part in the advancement of initiation, promotion, and progression of tumourigenesis through the development of a protumorigenic microenvironment. This can be achieved by exosomes through the suppression of the immune system and prevention of uncontrolled inflammation. For example, exosomes can induce immunosuppression through the initiation of apoptosis in immune cells (111). In Epstein-Barr virus (EBV)-infected nasopharyngeal cells, released exosomes contain high concentrations of galectin-9 protein, which is able to induce apoptosis in mature Th1 lymphocytes $(112,113)$. Tumor-derived exosomes have also exhibited the ability to trigger Fas-dependent apoptosis of activated $\mathrm{CD}^{+} \mathrm{T}$ cells in both colorectal cancer as well as melanoma cells, thus contributing to tumor escape from the immune system $(56,114,115)$.

\section{Natural Killer Cells}

Natural killer (NK) cells are innate lymphoid cells that are involved in the protection of the host against infection and cancerous cells, as well as the regulation of homeostasis via destruction of activated immune cells (116, 117). Tumorderived exosomes have been reported to suppress the activity of NK cells as a means to promote immune escape of cancer cells. These tumor-derived exosomes are able to arrest NK cell development through the release of the immunosuppressive cytokine transforming growth factor- $\beta$ (TGF- $\beta$ ) (118). Furthermore, in a study using syngeneic BALB/c and nude mice, exosomes derived from TS/A or 4T.1 murine mammary tumor cells was able to induce tumor growth by inhibiting IL-2 mediated activation of NK cells (119). NK cell proliferation was also reported to be inhibited by exosomes produced by human breast and melanoma cell lines (119). Tumor derived exosomes have also been shown to induce Smad phosphorylation, impair cell cytotoxicity, and decrease NKG2D receptor expression, which will result in the loss of tumor cell surface markers, that would in normal situations stimulate immune response (120-122). Furthermore, exosomes are able to act as decoys by secreting NKG2D ligands, which will down-regulate NKG2D receptor-mediated cytotoxicity of NK cells (123).

\section{Regulatory T Cells (Treg)}

Regulatory $\mathrm{T}$ cells (Tregs) are a dedicated subset of a larger, heterogeneous population of $\mathrm{CD}^{+}{ }^{+} \mathrm{T}$ cells $(124,125)$, that has an important function in immune homeostasis, as well as a role in the regulation of various inflammatory process including autoimmunity, tissue injury, and transplant rejection (126-128). In cancer, Tregs have been found to be accumulated in the tumor microenvironment and plays a significant role in maintenance of immune tolerance via the suppression of various immune cells such as T lymphocytes (129), B lymphocytes (130), NK cells (131), dendritic cells (132), and macrophages (133). Patients with high density of Tregs in the tumor stroma have also been shown to have a worse prognosis in comparison to those with low density of Tregs (134).

Tumor derived exosomes can initiate immunosuppression through the indirect expansion and activation of Treg. This will lead to an up-regulation of Treg suppression function and enhancing Treg resistance to apoptosis $(135,136)$. Szajnik et al. reported that the expression of $\mathrm{CD} 24^{+} \mathrm{CD} 25^{+} \mathrm{FOXP}^{+}$ Treg cells is significantly increased in the peripheral blood of myeloma patients in comparison to non-cancerous donors, and the serum of these patients contained high concentrations of tumor-derived exosomes. They further determined that tumorderived exosomes was able to induce Treg expansion through mechanisms involving phosphorylation of relevant transcription factors IL-10 and TGF- $\beta 1$ (136).

\section{Macrophages}

In hepatocellular carcinoma, exosomes are able to indirectly down-regulate expression of the pro-inflammatory cytokine IL-6 as a means of suppressing the immune system. A study has demonstrated that TLR4, a fundamental signaling pathway that mediates inflammation $(137,138)$, was found to regulate uncontrolled inflammation through the release of exosomes via the MyD88 dependent pathway. Exosomes in turn transferred miR-let-7b to macrophages to inhibit the expression of proinflammatory IL-6, thus weakening tumor inflammation (139).

In another study, macrophages were found to be affected by the overexpression of miR-940 released by exosomes 
TABLE 1 | A summary of the effects of tumor-derived exosomes on the inflammatory process.

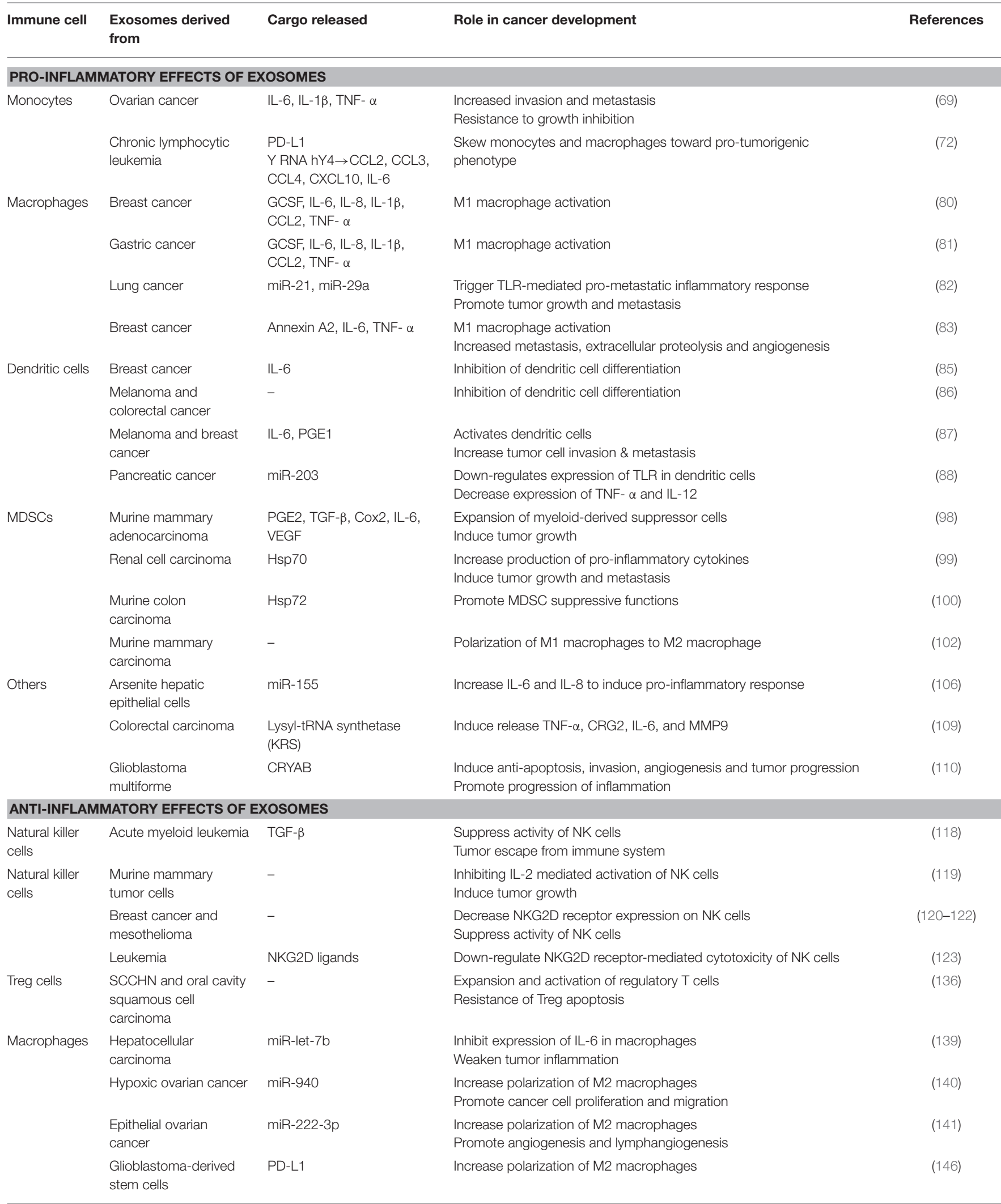


TABLE 1 | Continued

\begin{tabular}{|c|c|c|c|c|}
\hline Immune cell & $\begin{array}{l}\text { Exosomes derived } \\
\text { from }\end{array}$ & Cargo released & Role in cancer development & References \\
\hline \multicolumn{5}{|c|}{ ANTI-INFLAMMATORY EFFECTS OF EXOSOMES } \\
\hline & Colon cancer & $\mathrm{miR}-1246$ & $\begin{array}{l}\text { Increase polarization of M2 macrophages } \\
\text { Increase epithelial-mesenchymal (EMT) promoting factors } \\
\text { Contribute to tumourigenesis and poor prognosis }\end{array}$ & $(147)$ \\
\hline & Breast cancer & $\operatorname{miR}-233$ & Tumor growth, invasion, and metastasis & $(148)$ \\
\hline & $\begin{array}{l}\text { EBV-infected } \\
\text { nasophyrangeal } \\
\text { carcinoma }\end{array}$ & Galectin-9 & Induce apoptosis of mature Th1 Iymphocytes & $(111)$ \\
\hline \multirow[t]{2}{*}{ Others } & $\begin{array}{l}\text { Squamous cell } \\
\text { carcinoma of the head } \\
\text { and neck (SCCHN) and } \\
\text { melanoma }\end{array}$ & - & $\begin{array}{l}\text { Fas-dependent apoptosis of activated } \mathrm{CD}^{+} \mathrm{T} \text { cells } \\
\text { Tumor escape from immune system }\end{array}$ & $(114)$ \\
\hline & Colorectal & - & $\begin{array}{l}\text { Fas-dependent apoptosis of activated CD8 }{ }^{+} \mathrm{T} \text { cells } \\
\text { Tumor escape from immune system }\end{array}$ & $(115)$ \\
\hline
\end{tabular}

derived from hypoxic ovarian cancer cells, inducing an antiinflammatory M2 polarization of macrophages to promote epithelial ovarian cancer (EOC) cell proliferation and migration (140). Another miRNA, miR-222-3p, enriched in EOC-derived exosomes, has also been revealed to increase polarization of M2 macrophages to promote angiogenesis and lymphangiogenesis in the tumor microenvironment to further encourage progression of EOC (141). Results indicated that miR-222-3p directly targets SOCS3 (suppressor of cytokine signaling 3), a negative regulator of the JAK/STAT pathway (142), which has been described to control the polarization of M1 and M2 macrophages (143-145). Suppression of SOCS3 expression was found to correlate with an increased expression of STAT3 activation (146).

A shift to M2 polarization can also be seen in macrophages exposed to exosomes released from colon cancer cells harboring gain-of-function mutant p53. These exosomes contain significantly high levels of miR-1246 which when transferred to neighboring macrophages stimulate heightened secretion of anti-inflammatory cytokines and epithelial-mesenchymal (EMT) promoting factors, thus contributing to tumourigenesis and poor prognosis (147). Another method through which exosomes mediate the polarization of M2 macrophages is by traversing the monocyte cytoplasm to induce a change in morphology and reorganization of the actin cytoskeleton. These exosomes secreted from glioblastoma-derived stem cells (GSCs) stimulate an increase of programmed death-ligand 1 (PD-L1) in monocytes, via association with STAT3, to mediate this suppressive switch (146).

In turn macrophages are also able to induce the release of exosomes to shuttle miRNAs into adjacent cells within the microenvironment. In response to activation by antiinflammatory molecule IL-4, macrophages from breast cancer tumors has demonstrated the ability to release exosomes containing miR-233 which plays a role in tumor growth, invasion, and metastasis via direct targeting of myocyte enhancer factor (Mef2c) (148).

\section{FUTURE PERSPECTIVE ON EXOSOMES IN IMMUNOTHERAPY}

As evidenced by the numerous studies, exosomes have the ability to suppress or activate the immune system through regulation of various immune cells. Due to key features of exosomes, such as their structure, composition, and their natural ability to transport and transfer their cargo among cells, exploitation of exosomes has been acknowledged as a feasible means of immunotherapy and treatment of cancer.

Loading of immunotherapy elements such as tumor associated antigens and adjuvants into exosomes have been reported to induce strong antigen-specific immunostimulatory effects (149). For example, in one study by Morishita et al. a murine melanoma B16-BL6 tumor cell-derived exosome was engineered to carry endogenous tumor antigen and streptavidinlactadherin, which facilitated the delivery of biotinylated $\mathrm{CpG}$ DNA. Delivery of these exosomes in immunized B16-BL6 tumor-bearing mice induced an in vivo anti-tumor effect (150). In another study by Mahmoodzadeh et al., MDA MB231 cancer cell exosomes were loaded with staphylococcal enterotoxin $\mathrm{B}$, which functions to activate $\mathrm{T}$ cells through the binding of MHCII. Esterogen receptor-negative (ER-) breast cancer cells treated with these exosomes were then observed to undergo significant apoptosis (151). Furthermore, studies have shown that loading of exosomes with miRNAs also has the potential to induce immune responses in their recipient cells. Momem-Heravi et al. demonstrated that Bcell-derived exosomes loaded with miR-155 was able to target macrophages in vitro and in vivo and induce the activation and differentiation of macrophages to an inflammatory M1phenotype (152). Currently there are a number of methods to load exosomes with the desired cargo, which includes electroporation, sonication, direct transfection, and simple incubation (153). However, further understanding of the limitations and advantages of these techniques must be 


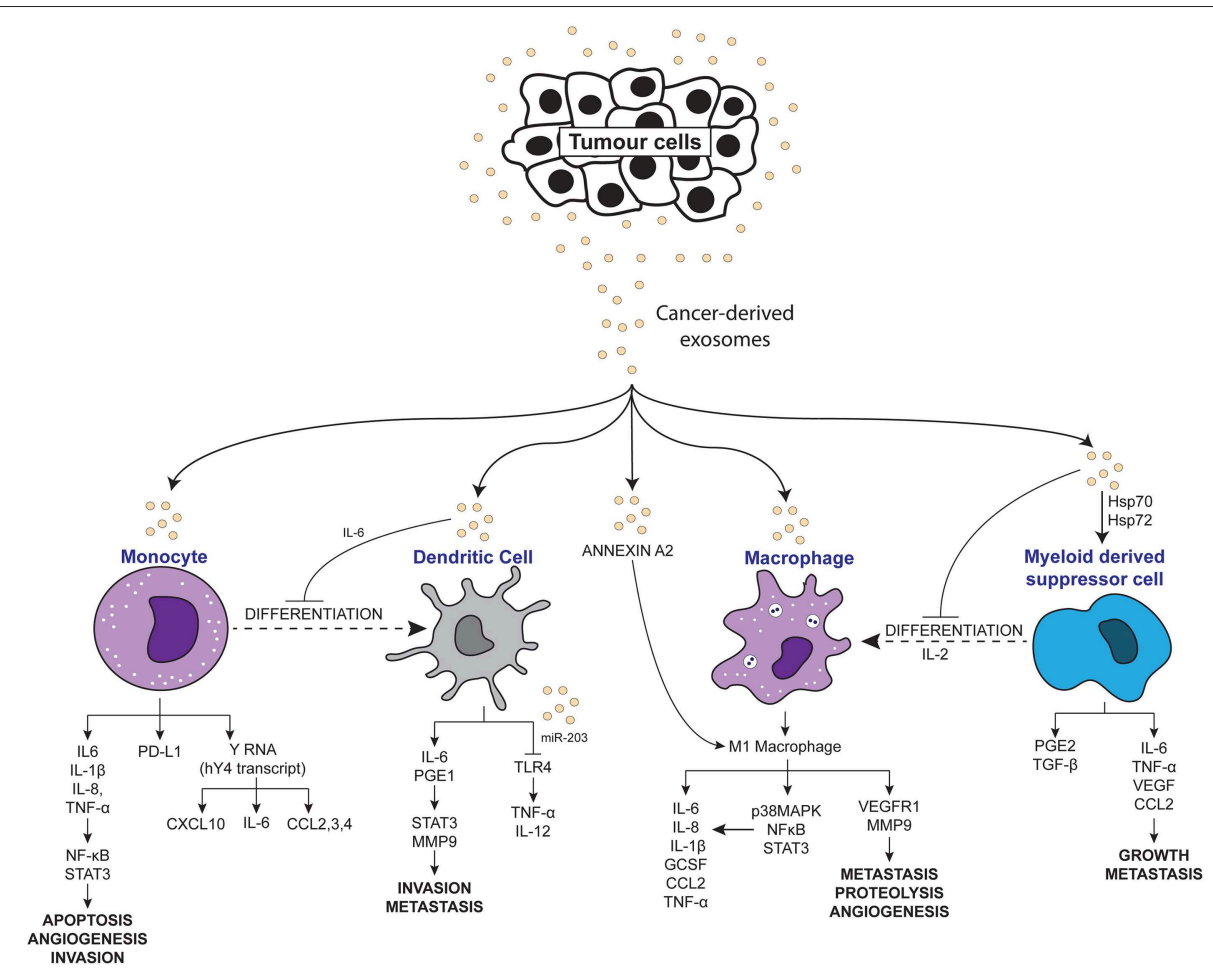

FIGURE 2 | Scheme depicting the pro-inflammatory effects of tumor-derived exosomes on immune molecules.

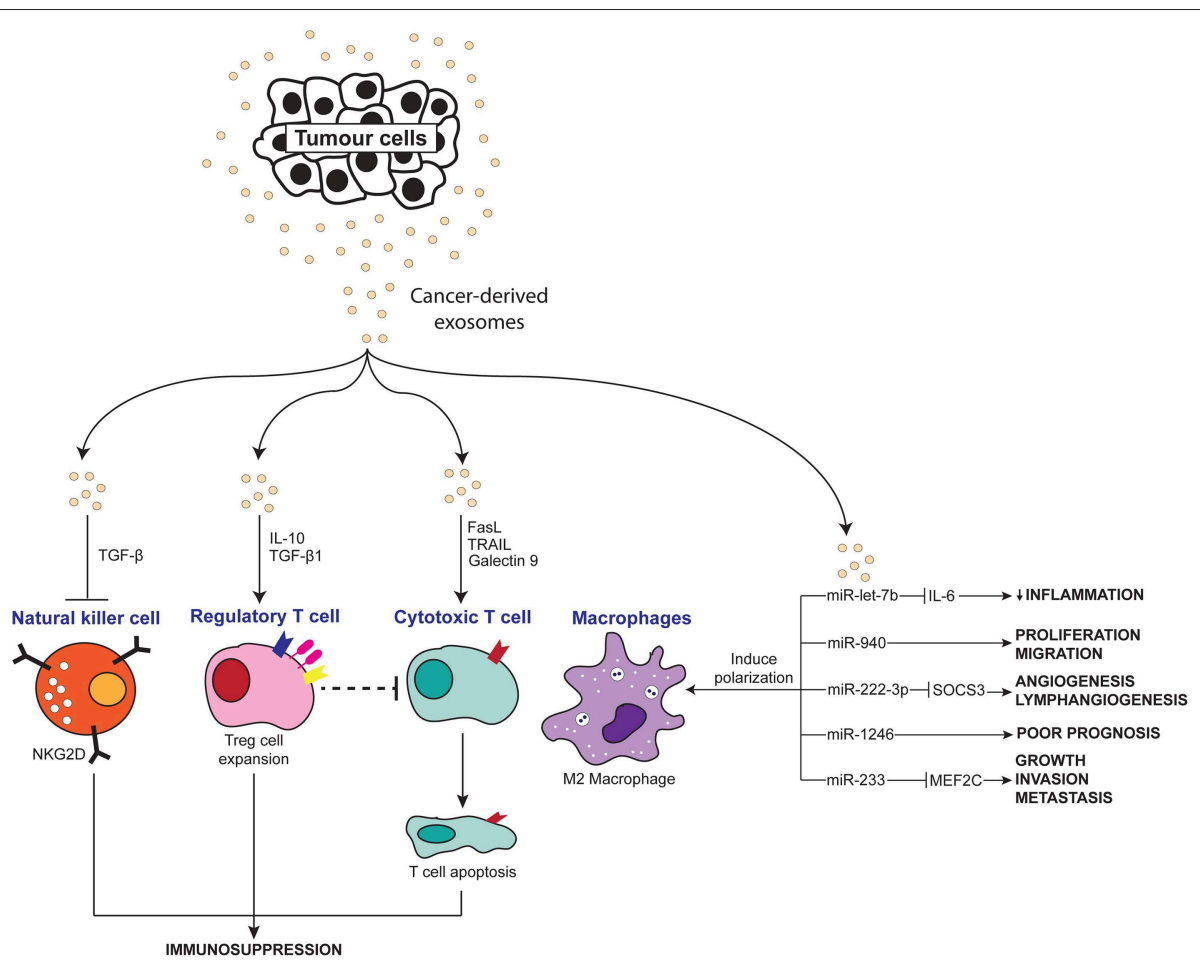

FIGURE 3 | Scheme depicting the anti-inflammatory effects of tumor-derived exosomes on immune molecules. 
studied to improve the potential of exosomes as a mode of immunotherapy.

Dendritic-cell (154)-derived exosome therapy is another is another means of inducing immune response for cancer treatment. In this therapy, dendritic cells with cancer peptides are stimulated to induce the production of DC-derived exosomes that carry the desired antigens. These DC-derived exosomes are then isolated, purified, and used to induce an immune response either through presenting of specific antigens to $\mathrm{T}$ cells to directly activate them, or through indirect activation through the presentation of antigen-MHC complex transfer to other dendritic cells $(52,53,155)$. The immune stimulatory effects of DC-derived exosomes have shown promising, but modest, results in two phase I human clinical trials in melanoma and non-small-cell lung cancer $(156,157)$. Subsequently, a phase II clinical trial in advanced non-smallcell lung cancer patients pre-treated with chemotherapy has shown limited efficacy of DC-derived exosomes to stimulate NK cell activation and improve the progression-free survival of patients (158).

The possibility of using exosomes as a means for cancer immunotherapy is still developing and there remain many challenges to overcome. Further knowledge must be obtained regarding the many roles that exosomes play in cancer and immunomodulation as well as the logistics for the development of exosomes as an immunotherapy. These include further research regarding techniques for effective isolation of exosomes, the possibility of offtarget effects due to the transfer of unknown materials in exosomes, as well as the amount, type, and biological

\section{REFERENCES}

1. Fernandes JV, Cobucci RN, Jatoba CA, Fernandes TA, de Azevedo JW, de Araujo JM. The role of the mediators of inflammation in cancer development. Pathol. Oncol Res. (2015) 21:527-34. doi: $10.1007 /$ s12253-015-9913-z

2. Landskron G, De la Fuente M, Thuwajit P, Thuwajit C, Hermoso MA. Chronic inflammation and cytokines in the tumor microenvironment. $J$ Immunol Res. (2014) 2014:19. doi: 10.1155/2014/149185

3. Norling LV, Serhan CN. Profiling in resolving inflammatory exudates identifies novel anti-inflammatory and pro-resolving mediators and signals for termination. J Intern Med. (2010) 268:15-24. doi: 10.1111/j.1365-2796.2010.02235.x

4. Bermejo-Martin JF, Martín-Loeches I, Bosinger S. Inflammation and infection in critical care medicine. Mediat Inflammat. (2014) 2014:456256. doi: $10.1155 / 2014 / 456256$

5. Karin M. Nuclear factor-кB in cancer development and progression. Nature. (2006) 441:431-6. doi: 10.1038/nature04870

6. Yu H, Kortylewski M, Pardoll D. Crosstalk between cancer and immune cells: role of STAT3 in the tumour microenvironment. Nat Rev Immunol. (2007) 7:41-51. doi: 10.1038/nri1995

7. Voronov E, Shouval DS, Krelin Y, Cagnano E, Benharroch D, Iwakura Y, et al. IL-1 is required for tumor invasiveness and angiogenesis. Proc Natl Acad Sci USA. (2003) 100:2645-50. doi: 10.1073/pnas.0437939100

8. Langowski JL, Zhang X, Wu L, Mattson JD, Chen T, Smith K. IL23 promotes tumour incidence and growth. Nature. (2006) 442:461-5. doi: $10.1038 /$ nature 04808 functions of the biomolecules to be loaded into the exosomes $(159,160)$.

\section{CONCLUSION}

Chronic inflammation has long been accepted to contribute to the development and pathogenesis of various cancers. Recently, many studies have explored the interaction of exosomes with the inflammatory system in promoting a pro-tumor microenvironment. As summarized in Table 1, Figures 2, 3, exosomes are able to induce pro-inflammatory and anti-inflammatory effects through the release of their cargo, which in turn modulates various cancer mechanisms including angiogenesis, metastasis, invasion, and apoptosis. Together these studies have demonstrated the importance of understanding the intricate crosstalk that exists between tumorderived exosomes and immune molecules, as a means to acquire further understanding of the development of cancers especially in those suffering inflammatory disorders.

\section{AUTHOR CONTRIBUTIONS}

NO drafted the manuscript. NA conceived the idea. NA and RJ provided critical feedback.

\section{FUNDING}

This manuscript was funded by the GGPM (Young Investigator Grant) Award by Universiti Kebangsaan Malaysia with the award number GGPM-2017-096.

9. Colotta F, Allavena P, Sica A, Garlanda C, Mantovani A. Cancer-related inflammation, the seventh hallmark of cancer: links to genetic instability. Carcinogenesis. (2009) 30:1073-81. doi: 10.1093/carcin/bgp127

10. Nowell PC. The clonal evolution of tumor cell populations. Science. (1976) 194:23-28. doi: 10.1126/science.959840

11. Yang D, Elner SG, Bian ZM, Till GO, Petty HR, Elner VM. Pro-inflammatory cytokines increase reactive oxygen species through mitochondria and NADPH oxidase in cultured RPE cells. Exp Eye Res. (2007) 85:462-72. doi: 10.1016/j.exer.2007.06.013

12. da Silva Krause M, Bittencourt A, Homem de Bittencourt PI Jr, McClenaghan NH, Flatt PR, Murphy C, et al. Physiological concentrations of interleukin-6 directly promote insulin secretion, signal transduction, nitric oxide release, and redox status in a clonal pancreatic beta-cell line and mouse islets. $J$ Endocrinol. (2012) 214:301-11. doi: 10.1530/JOE-12-0223

13. Allavena P, Sica A, Garlanda C, Mantovani A. The Yin-Yang of tumorassociated macrophages in neoplastic progression and immune surveillance. Immunol Rev. (2008) 222:155-61. doi: 10.1111/j.1600-065X.2008.00607.x

14. Mantovani A, Bottazzi B, Colotta F, Sozzani S, Ruco L. The origin and function of tumor-associated macrophages. Immunol Today. (1992) 13:26570. doi: 10.1016/0167-5699(92)90008-U

15. Saccani A, Schioppa T, Porta C, Biswas SK, Nebuloni M, Vago L, et al. p50 nuclear factor- $\mathrm{\kappa} \mathrm{B}$ overexpression in tumor-associated macrophages inhibits M1 inflammatory responses and antitumor resistance. Cancer Res. (2006) 66:11432-40. doi: 10.1158/0008-5472.CAN-06-1867

16. Hagemann T, Lawrence T, McNeish I, Charles KA, Kulbe H, Thompson RG, et al. "Re-educating" tumor-associated macrophages by targeting NF- $\mathrm{B}$. J Exp Med. (2008) 205:1261-8. doi: 10.1084/jem.20080108 
17. Keller S, Sanderson MP, Stoeck A, Altevogt P. Exosomes: from biogenesis and secretion to biological function. Immunol Lett. (2006) 107:102-8. doi: 10.1016/j.imlet.2006.09.005

18. Colombo M, Raposo G, Thery C. Biogenesis, secretion, and intercellular interactions of exosomes and other extracellular vesicles. Ann Rev Cell Dev Biol. (2014) 30:255-89. doi: 10.1146/annurev-cellbio-101512-122326

19. Thery C, Zitvogel L, Amigorena S. Exosomes: composition, biogenesis and function. Nat Rev Immunol. (2002) 2:569-79. doi: 10.1038/nri855

20. Cocucci E, Meldolesi J. Ectosomes and exosomes: shedding the confusion between extracellular vesicles. Trends Cell Biol. (2015) 25:364-72. doi: 10.1016/j.tcb.2015.01.004

21. Trajkovic K, Hsu C, Chiantia S, Rajendran L, Wenzel D, Wieland F, et al. Ceramide triggers budding of exosome vesicles into multivesicular endosomes. Science. (2008) 319:1244-7. doi: 10.1126/science.1153124

22. Silva M, Melo SA. Non-coding RNAs in exosomes: new players in cancer biology. Curr Genom. (2015) 16:295-303. doi: 10.2174/1389202916666150707154719

23. Crescitelli R, Lasser C, Szabo TG, Kittel A, Eldh M, Dianzani I, et al. Distinct RNA profiles in subpopulations of extracellular vesicles: apoptotic bodies, microvesicles and exosomes. J Extracell Vesicles. (2013) 2:20677. doi: 10.3402/jev.v2i0.20677

24. Kalra H, Simpson RJ, Ji H, Aikawa E, Altevogt P, Askenase P, et al. Vesiclepedia: a compendium for extracellular vesicles with continuous community annotation. PLoS Biol. (2012) 10:e1001450. doi: 10.1371/journal.pbio.1001450

25. Record M, Subra C, Silvente-Poirot S, Poirot M. Exosomes as intercellular signalosomes and pharmacological effectors. Biochem Pharmacol. (2011) 81:1171-82. doi: 10.1016/j.bcp.2011.02.011

26. Zhang X, Yuan X, Shi H, Wu L, Qian H, Xu W. Exosomes in cancer: small particle, big player. J Hematol Oncol. (2015) 8:83. doi: 10.1186/s13045-015-0181-x

27. S ELA, Mager I, Breakefield XO, Wood MJ. Extracellular vesicles: biology and emerging therapeutic opportunities. Nat Rev Drug Discov. (2013) 12:347-57. doi: $10.1038 / \mathrm{nrd} 3978$

28. Kucharzewska P, Belting M. Emerging roles of extracellular vesicles in the adaptive response of tumour cells to microenvironmental stress. J Extracell Vesicles. (2013) 2:20304. doi: 10.3402/jev.v2i0.20304

29. Kahlert C, Melo SA, Protopopov A, Tang J, Seth S, Koch M, et al. Identification of double-stranded genomic DNA spanning all chromosomes with mutated KRAS and p53 DNA in the serum exosomes of patients with pancreatic cancer. J Biol Chem. (2014) 289:3869-75. doi: 10.1074/jbc.C113.532267

30. Valadi H, Ekstrom K, Bossios A, Sjostrand M, Lee JJ, Lotvall JO. Exosome-mediated transfer of mRNAs and microRNAs is a novel mechanism of genetic exchange between cells. Nat Cell Biol. (2007) 9:654-9. doi: $10.1038 /$ ncb1596

31. Balaj L, Lessard R, Dai L, Cho YJ, Pomeroy SL, Breakefield XO, et al. Tumour microvesicles contain retrotransposon elements and amplified oncogene sequences. Nat Commun. (2011) 2:180. doi: 10.1038/ncomms1180

32. De Toro J, Herschlik L, Waldner C, Mongini C. Emerging roles of exosomes in normal and pathological conditions: new insights for diagnosis and therapeutic applications. Front Immunol. (2015) 6:203. doi: 10.3389/fimmu.2015.00203

33. Lee Y, El Andaloussi S, Wood MJ. Exosomes and microvesicles: extracellular vesicles for genetic information transfer and gene therapy. Hum Mol Genet. (2012) 21:R125-34. doi: 10.1093/hmg/dds317

34. Keller S, Ridinger J, Rupp AK, Janssen JW, Altevogt P. Body fluid derived exosomes as a novel template for clinical diagnostics. J Transl Med. (2011) 9:86. doi: 10.1186/1479-5876-9-86

35. Lasser C, Alikhani VS, Ekstrom K, Eldh M, Paredes PT, Bossios A, et al. Human saliva, plasma and breast milk exosomes contain RNA. uptake by macrophages. J Transl Med. (2011) 9:9. doi: 10.1186/1479-5876-9-9

36. Tietje A, Maron KN, Wei Y, Feliciano DM. Cerebrospinal fluid extracellular vesicles undergo age dependent declines and contain known and novel non-coding RNAs. PLoS ONE. (2014) 9:e113116. doi: 10.1371/journal.pone.0113116

37. Abd Elmageed ZY, Yang Y, Thomas R, Ranjan M, Mondal D, Moroz K, et al. Neoplastic reprogramming of patient-derived adipose stem cells by prostate cancer cell-associated exosomes. Stem Cells. (2014) 32:983-97. doi: 10.1002/stem.1619

38. Melo SA, Sugimoto H, O'Connell JT, Kato N, Villanueva A, Vidal A, et al. Cancer exosomes perform cell-independent microRNA biogenesis and promote tumorigenesis. Cancer Cell. (2014) 26:707-21. doi: 10.1016/j.ccell.2014.09.005

39. Soldevilla B, Rodriguez M, San Millan C, Garcia V, Fernandez-Perianez R, Gil-Calderon B, et al. Tumor-derived exosomes are enriched in DeltaNp73, which promotes oncogenic potential in acceptor cells and correlates with patient survival. Hum Mol Genet. (2014) 23:467-78. doi: 10.1093/hmg/ddt437

40. Umezu T, Ohyashiki K, Kuroda M, Ohyashiki JH. Leukemia cell to endothelial cell communication via exosomal miRNAs. Oncogene. (2013) 32:2747-55. doi: 10.1038/onc.2012.295

41. Peinado H, Aleckovic M, Lavotshkin S, Matei I, Costa-Silva B, MorenoBueno $\mathrm{G}$, et al. Melanoma exosomes educate bone marrow progenitor cells toward a pro-metastatic phenotype through MET. Nat Med. (2012) 18:883-91. doi: 10.1038/nm.2753

42. Taylor DD, Gercel-Taylor C. MicroRNA signatures of tumor-derived exosomes as diagnostic biomarkers of ovarian cancer. Gynecol Oncol. (2008) 110:13-21. doi: 10.1016/j.ygyno.2008.04.033

43. Gallo A, Tandon M, Alevizos I, Illei GG. The majority of microRNAs detectable in serum and saliva is concentrated in exosomes. PLoS ONE. (2012) 7:e30679. doi: 10.1371/journal.pone.0030679

44. Tanaka Y, Kamohara H, Kinoshita K, Kurashige J, Ishimoto T, Iwatsuki $\mathrm{M}$, et al. Clinical impact of serum exosomal microRNA-21 as a clinical biomarker in human esophageal squamous cell carcinoma. Cancer. (2013) 119:1159-67. doi: 10.1002/cncr.27895

45. Li Q, Shao Y, Zhang X, Zheng T, Miao M, Qin L, et al. Plasma long noncoding RNA protected by exosomes as a potential stable biomarker for gastric cancer. Tumour Biol. (2015) 36:2007-12. doi: 10.1007/s13277-014-2807-y

46. Wang J, Zhou Y, Lu J, Sun Y, Xiao H, Liu M, et al. Combined detection of serum exosomal miR-21 and HOTAIR as diagnostic and prognostic biomarkers for laryngeal squamous cell carcinoma. Med Oncol. (2014) 31:148. doi: 10.1007/s12032-014-0148-8

47. Baj-Krzyworzeka M, Majka M, Pratico D, Ratajczak J, Vilaire G, Kijowski $\mathrm{J}$, et al. Platelet-derived microparticles stimulate proliferation, survival, adhesion, and chemotaxis of hematopoietic cells. Exp Hematol. (2002) 30:450-9. doi: 10.1016/S0301-472X(02)00791-9

48. Sprague DL, Elzey BD, Crist SA, Waldschmidt TJ, Jensen RJ, Ratliff TL. Platelet-mediated modulation of adaptive immunity: unique delivery of CD154 signal by platelet-derived membrane vesicles. Blood. (2008) 111:5028-36. doi: 10.1182/blood-2007-06-097410

49. Valenti R, Huber V, Iero M, Filipazzi P, Parmiani G, Rivoltini L. Tumorreleased microvesicles as vehicles of immunosuppression. Cancer Res. (2007) 67:2912-5. doi: 10.1158/0008-5472.CAN-07-0520

50. Thery C, Regnault A, Garin J, Wolfers J, Zitvogel L, Ricciardi-Castagnoli P, et al. Molecular characterization of dendritic cell-derived exosomes. Selective accumulation of the heat shock protein hsc73. J Cell Biol. (1999) 147:599610. doi: $10.1083 /$ jcb.147.3.599

51. Luketic L, Delanghe J, Sobol PT, Yang P, Frotten E, Mossman KL, et al. Antigen presentation by exosomes released from peptide-pulsed dendritic cells is not suppressed by the presence of active CTL. J Immunol. (2007) 179:5024-32. doi: 10.4049/jimmunol.179.8.5024

52. Admyre C, Johansson SM, Paulie S, Gabrielsson S. Direct exosome stimulation of peripheral human $\mathrm{T}$ cells detected by ELISPOT. Eur J Immunol. (2006) 36:1772-81. doi: 10.1002/eji.200535615

53. Utsugi-Kobukai S, Fujimaki H, Hotta C, Nakazawa M, Minami M. MHC class I-mediated exogenous antigen presentation by exosomes secreted from immature and mature bone marrow derived dendritic cells. Immunol Lett. (2003) 89:125-31. doi: 10.1016/S0165-2478(03)00128-7

54. Lugini L, Cecchetti S, Huber V, Luciani F, Macchia G, Spadaro F, et al. Immune surveillance properties of human NK cell-derived exosomes. $J$ Immunol. (2012) 189:2833-42. doi: 10.4049/jimmunol.1101988

55. Skokos D, Botros HG, Demeure C, Morin J, Peronet R, Birkenmeier G, et al. Mast cell-derived exosomes induce phenotypic and functional maturation of dendritic cells and elicit specific immune responses in vivo. J Immunol. (2003) 170:3037-45. doi: 10.4049/jimmunol.170.6.3037 
56. Andreola G, Rivoltini L, Castelli C, Huber V, Perego P, Deho P, et al. Induction of lymphocyte apoptosis by tumor cell secretion of FasL-bearing microvesicles. J Exp Med. (2002) 195:1303-16. doi: 10.1084/jem.20011624

57. Taylor DD, Gercel-Taylor C. Tumour-derived exosomes and their role in cancer-associated T-cell signalling defects. Br J Cancer. (2005) 92:305-11. doi: 10.1038/sj.bjc.6602316

58. Clayton A, Mason M. Exosomes in tumour immunity. Curr Oncol. (2009) 16:46-49. doi: 10.3747/co.v16i3.367

59. Clayton A, Mitchell JP, Court J, Mason MD, Tabi Z. Human tumor-derived exosomes selectively impair lymphocyte responses to interleukin-2. Cancer Res. (2007) 67:7458-66. doi: 10.1158/0008-5472.CAN-06-3456

60. Yang J, Zhang L, Yu C, Yang XF, Wang H. Monocyte and macrophage differentiation: circulation inflammatory monocyte as biomarker for inflammatory diseases. Biomark Res. (2014) 2:1. doi: 10.1186/2050-7771-2-1

61. Auffray C, Sieweke MH, Geissmann F. Blood monocytes: development, heterogeneity, and relationship with dendritic cells. Ann Rev Immunol. (2009) 27:669-92. doi: 10.1146/annurev.immunol.021908.132557

62. Gordon S, Taylor PR. Monocyte and macrophage heterogeneity. Nat Rev Immunol. (2005) 5:953-64. doi: 10.1038/nri1733

63. Yasaka T, Mantich NM, Boxer LA, Baehner RL. Functions of human monocyte and lymphocyte subsets obtained by countercurrent centrifugal elutriation: differing functional capacities of human monocyte subsets. $J$ Immunol. (1981) 127:1515-8.

64. Kurihara T, Warr G, Loy J, Bravo R. Defects in macrophage recruitment and host defense in mice lacking the CCR2 chemokine receptor. J Exp Med. (1997) 186:1757-62. doi: 10.1084/jem.186.10.1757

65. Mantovani A, Muzio M, Garlanda C, Sozzani S, Allavena P. Macrophage control of inflammation: negative pathways of regulation of inflammatory cytokines. In: Chronic Obstructive Pulmonary Disease: Pathogenesis to Treatment. Milan (2008). doi: 10.1002/0470868678.ch8

66. Atretkhany KN, Drutskaya MS, Nedospasov SA, Grivennikov SI, Kuprash DV. Chemokines, cytokines and exosomes help tumors to shape inflammatory microenvironment. Pharmacol Therapeut. (2016) 168:98-112. doi: 10.1016/j.pharmthera.2016.09.011

67. Zamarron BF, Chen WJ. Dual roles of immune cells and their factors in cancer development and progression. Int J Biol Sci. (2011) 7:651-8. doi: 10.7150/ijbs.7.651

68. Richards DM, Hettinger J, Feuerer M. Monocytes and macrophages in cancer: development and functions. Cancer Microenviron. (2013) 6:179-91. doi: 10.1007/s12307-012-0123-x

69. Bretz NP, Ridinger J, Rupp AK, Rimbach K, Keller S, Rupp C, et al. Body fluid exosomes promote secretion of inflammatory cytokines in monocytic cells via Toll-like receptor signaling. J Biol Chem. (2013) 288:36691-702. doi: 10.1074/jbc.M113.512806

70. Karin M, Cao Y, Greten FR, Li ZW. NF-кB in cancer: from innocent bystander to major culprit. Nat Rev Cancer. (2002) 2:301-10. doi: $10.1038 / \operatorname{nrc} 780$

71. Bromberg J, Darnell JE Jr. The role of STATs in transcriptional control and their impact on cellular function. Oncogene. (2000) 19:2468-73. doi: 10.1038/sj.onc. 1203476

72. Haderk F, Schulz R, Iskar M, Cid LL, Worst T, Willmund KV, et al. Tumorderived exosomes modulate PD-L1 expression in monocytes. Sci Immunol. (2017) 2:eaah5509. doi: 10.1126/sciimmunol.aah5509

73. Kasahara T, Matsushima K. Macrophage signaling, apoptosis, lectins and leukocyte trafficking. Trends Immunol. (2001) 22:593-4. doi: 10.1016/S1471-4906(01)02057-9

74. Laskin DL, Sunil VR, Gardner CR, Laskin JD. Macrophages and tissue injury: agents of defense or destruction? Ann Rev Pharmacol Toxicol. (2011) 51:267-88. doi: 10.1146/annurev.pharmtox.010909.1 05812

75. Murray PJ, Wynn TA. Protective and pathogenic functions of macrophage subsets. Nat Rev Immunol. (2011) 11:723-37. doi: 10.1038/nri3073

76. Mantovani A, Sozzani S, Locati M, Allavena P, Sica A. Macrophage polarization: tumor-associated macrophages as a paradigm for polarized M2 mononuclear phagocytes. Trends Immunol. (2002) 23:549-55. doi: 10.1016/S1471-4906(02)02302-5

77. Mosser DM, Edwards JP. Exploring the full spectrum of macrophage activation. Nat Rev Immunol. (2008) 8:958-69. doi: 10.1038/nri2448
78. Mantovani A, Sica A. Macrophages, innate immunity and cancer: balance, tolerance, and diversity. Curr Opin Immunol. (2010) 22:231-7. doi: 10.1016/j.coi.2010.01.009

79. Biswas SK, Gangi L, Paul S, Schioppa T, Saccani A, Sironi M, et al. A distinct and unique transcriptional program expressed by tumor-associated macrophages (defective NF- $\mathrm{B}$ and enhanced IRF-3/STAT1 activation). Blood. (2006) 107:2112-22. doi: 10.1182/blood-2005-01-0428

80. Chow A, Zhou W, Liu L, Fong MY, Champer J, Van Haute D, et al. Macrophage immunomodulation by breast cancer-derived exosomes requires Toll-like receptor 2-mediated activation of NF-кB. Sci Rep. (2014) 4:5750. doi: 10.1038/srep05750

81. Wu L, Zhang X, Zhang B, Shi H, Yuan X, Sun Y, et al. Exosomes derived from gastric cancer cells activate NF- $\mathrm{B}$ pathway in macrophages to promote cancer progression. Tumour Biol. (2016) 37:12169-80. doi: 10.1007/s13277-016-5071-5

82. Fabbri M, Paone A, Calore F, Galli R, Gaudio E, Santhanam R, et al. MicroRNAs bind to Toll-like receptors to induce prometastatic inflammatory response. Proc Natl Acad Sci USA. (2012) 109:E2110-6. doi: 10.1073/pnas.1209414109

83. Maji S, Chaudhary P, Akopova I, Nguyen PM, Hare RJ, Gryczynski I, et al. Exosomal annexin II promotes angiogenesis and breast cancer metastasis. Mol Cancer Res. (2017) 15:93-105. doi: 10.1158/1541-7786.MCR-16-0163

84. Banchereau J, Steinman RM. Dendritic cells and the control of immunity. Nature. (1998) 392:245-52. doi: 10.1038/32588

85. Yu S, Liu C, Su K, Wang J, Liu Y, Zhang L, et al. Tumor exosomes inhibit differentiation of bone marrow dendritic cells. J Immunol. (2007) 178:6867-75. doi: 10.4049/jimmunol.178.11.6867

86. Valenti R, Huber V, Filipazzi P, Pilla L, Sovena G, Villa A, et al. Human tumor-released microvesicles promote the differentiation of myeloid cells with transforming growth factor-beta-mediated suppressive activity on T lymphocytes. Cancer Res. (2006) 66:9290-8. doi: 10.1158/0008-5472.CAN-06-1819

87. Shen Y, Guo D, Weng L, Wang S, Ma Z, Yang Y, et al. Tumorderived exosomes educate dendritic cells to promote tumor metastasis via HSP72/HSP105-TLR2/TLR4 pathway. Oncoimmunology. (2017) 6:e1362527. doi: 10.1080/2162402X.2017.1362527

88. Zhou M, Chen J, Zhou L, Chen W, Ding G, Cao L. Pancreatic cancer derived exosomes regulate the expression of TLR4 in dendritic cells via miR-203. Cell Immunol. (2014) 292:65-9. doi: 10.1016/j.cellimm.2014.09.004

89. David JM, Dominguez C, Hamilton DH, Palena C. The IL-8/IL-8R axis: a double agent in tumor immune resistance. Vaccines. (2016) 4:E22. doi: 10.3390/vaccines4030022

90. Almand B, Clark JI, Nikitina E, van Beynen J, English NR, Knight SC, et al. Increased production of immature myeloid cells in cancer patients: a mechanism of immunosuppression in cancer. J Immunol. (2001) 166:678-89. doi: 10.4049/jimmunol.166.1.678

91. Diaz-Montero CM, Salem ML, Nishimura MI, Garrett-Mayer E, Cole DJ, Montero AJ. Increased circulating myeloid-derived suppressor cells correlate with clinical cancer stage, metastatic tumor burden, and doxorubicincyclophosphamide chemotherapy. Cancer Immunol Immunother. (2009) 58:49-59. doi: 10.1007/s00262-008-0523-4

92. Marigo I, Dolcetti L, Serafini P, Zanovello P, Bronte V. Tumor-induced tolerance and immune suppression by myeloid derived suppressor cells. Immunol Rev. (2008) 222:162-79. doi: 10.1111/j.1600-065X.2008.00602.x

93. Kusmartsev S, Gabrilovich DI. Inhibition of myeloid cell differentiation in cancer: the role of reactive oxygen species. J Leukoc Biol. (2003) 74:186-96. doi: 10.1189/jlb.0103010

94. Youn JI, Gabrilovich DI. The biology of myeloid-derived suppressor cells: the blessing and the curse of morphological and functional heterogeneity. Eur J Immunol. (2010) 40:2969-75. doi: 10.1002/eji.201040895

95. Whiteside TL. Exosomes and tumor-mediated immune suppression. J Clin Invest. (2016) 126:1216-23. doi: 10.1172/JCI81136

96. Musolino C, Allegra A, Pioggia G, Gangemi S. Immature myeloid-derived suppressor cells: a bridge between inflammation and cancer (Review). Oncol Rep. (2017) 37:671-83. doi: 10.3892/or.2016.5291

97. Ostrand-Rosenberg S, Sinha P. Myeloid-derived suppressor cells: linking inflammation and cancer. J Immunol. (2009) 182:4499-506. doi: 10.4049/jimmunol.0802740 
98. Xiang X, Poliakov A, Liu C, Liu Y, Deng ZB, Wang J, et al. Induction of myeloid-derived suppressor cells by tumor exosomes. Int J Cancer. (2009) 124:2621-33. doi: 10.1002/ijc.24249

99. Diao J, Yang X, Song X, Chen S, He Y, Wang Q, et al. Exosomal Hsp70 mediates immunosuppressive activity of the myeloid-derived suppressor cells via phosphorylation of Stat3. Med Oncol. (2015) 32:453. doi: 10.1007/s12032-014-0453-2

100. Chalmin F, Ladoire S, Mignot G, Vincent J, Bruchard M, Remy-Martin JP, et al. Membrane-associated Hsp72 from tumor-derived exosomes mediates STAT3-dependent immunosuppressive function of mouse and human myeloid-derived suppressor cells. J Clin Invest. (2010) 120:457-71. doi: 10.1172/JCI40483

101. Liu Y, Xiang X, Zhuang X, Zhang S, Liu C, Cheng Z, et al. Contribution of MyD88 to the tumor exosome-mediated induction of myeloid derived suppressor cells. Am J Pathol. (2010) 176:2490-9. doi: 10.2353/ajpath.2010.090777

102. Burke M, Choksawangkarn W, Edwards N, Ostrand-Rosenberg S, Fenselau C. Exosomes from myeloid derived suppressor cells carry biologically active proteins. J Proteome Res. (2014) 13:836-43. doi: 10.1021/pr400879c

103. Abels ER. Introduction to extracellular vesicles: biogenesis, RNA cargo selection, content, release, and uptake. Cell Mol Neurobiol. (2016) 36:301-12. doi: 10.1007/s10571-016-0366-Z

104. Choi DS, Kim DK, Kim YK, Gho YS. Proteomics, transcriptomics and lipidomics of exosomes and ectosomes. Proteomics. (2013) 13:1554-71. doi: 10.1002/pmic.201200329

105. Thakur BK, Zhang H, Becker A, Matei I, Huang Y, Costa-Silva B, et al. Double-stranded DNA in exosomes: a novel biomarker in cancer detection. Cell Res. (2014) 24:766-9. doi: 10.1038/cr.2014.44

106. Chen C, Luo F, Liu X, Lu L, Xu H, Yang Q, et al. NF-kB-regulated exosomal miR-155 promotes the inflammation associated with arsenite carcinogenesis. Cancer Lett. (2017) 388:21-33. doi: 10.1016/j.canlet.2016.11.027

107. Jablonski KA, Gaudet AD, Amici SA, Popovich PG, Guerau-de-Arellano M. Control of the Inflammatory Macrophage Transcriptional Signature by miR-155. PLoS ONE. (2016) 11:e0159724. doi: 10.1371/journal.pone.0159724

108. Bala S, Marcos M, Kodys K, Csak T, Catalano D, Mandrekar P, et al. Up-regulation of microRNA-155 in macrophages contributes to increased tumor necrosis factor $\alpha(\mathrm{TNF} \alpha)$ production via increased mRNA half-life in alcoholic liver disease. J Biol Chem. (2011) 286:1436-44. doi: 10.1074/jbc.M110.145870

109. Kim SB, Kim HR, Park MC, Cho S, Goughnour PC, Han D, et al. Caspase-8 controls the secretion of inflammatory lysyl-tRNA synthetase in exosomes from cancer cells. J Cell Biol. (2017) 216:2201-16. doi: 10.1083/jcb.2016 05118

110. Kore RA, Abraham EC. Inflammatory cytokines, interleukin-1 beta and tumor necrosis factor-alpha, upregulated in glioblastoma multiforme, raise the levels of CRYAB in exosomes secreted by U373 glioma cells. Biochem Biophys Res Commun. (2014) 453:326-31. doi: 10.1016/j.bbrc.2014.09.068

111. Barros FM, Carneiro F, Machado JC, Melo SA. Exosomes and immune response in cancer: friends or foes? Front Immunol. (2018) 9:730. doi: 10.3389/fimmu.2018.00730

112. Klibi J, Niki T, Riedel A, Pioche-Durieu C, Souquere S, Rubinstein E, et al. Blood diffusion and Th1-suppressive effects of galectin-9-containing exosomes released by Epstein-Barr virus-infected nasopharyngeal carcinoma cells. Blood. (2009) 113:1957-66. doi: 10.1182/blood-2008-02-142596

113. Keryer-Bibens C, Pioche-Durieu C, Villemant C, Souquere S, Nishi N, Hirashima $\mathrm{M}$, et al. Exosomes released by EBV-infected nasopharyngeal carcinoma cells convey the viral latent membrane protein 1 and the immunomodulatory protein galectin 9. BMC Cancer. (2006) 6:283. doi: 10.1186/1471-2407-6-283

114. Wieckowski EU, Visus C, Szajnik M, Szczepanski MJ, Storkus WJ, Whiteside TL. Tumor-derived microvesicles promote regulatory $\mathrm{T}$ cell expansion and induce apoptosis in tumor-reactive activated CD8 + T lymphocytes. $J$ Immunol. (2009) 183:3720-30. doi: 10.4049/jimmunol.0900970

115. Huber V, Fais S, Iero M, Lugini L, Canese P, Squarcina P, et al. Human colorectal cancer cells induce T-cell death through release of proapoptotic microvesicles: role in immune escape. Gastroenterology. (2005) 128:1796804. doi: $10.1053 /$ j.gastro.2005.03.045
116. Parisi L, Bassani B, Tremolati M, Gini E, Farronato G, Bruno A. Natural killer cells in the orchestration of chronic inflammatory diseases. J Immunol Res. (2017) 2017:4218254. doi: 10.1155/2017/4218254

117. Zitti B, Bryceson YT. Natural killer cells in inflammation and autoimmunity. Cytokine Growth Factor Rev. (2018) 42:37-46. doi: 10.1016/j.cytogfr.2018.08.001

118. Szczepanski MJ, Szajnik M, Welsh A, Whiteside TL, Boyiadzis M. Blast-derived microvesicles in sera from patients with acute myeloid leukemia suppress natural killer cell function via membrane-associated transforming growth factor-betal. Haematologica. (2011) 96:1302-9. doi: 10.3324/haematol.2010.039743

119. Liu C, Yu S, Zinn K, Wang J, Zhang L, Jia Y, et al. Murine mammary carcinoma exosomes promote tumor growth by suppression of NK cell function. J Immunol. (2006) 176:1375-85. doi: 10.4049/jimmunol.176.3.1375

120. Clayton A, Tabi Z. Exosomes and the MICA-NKG2D system in cancer. Blood Cells Mol Dis. (2005) 34:206-13. doi: 10.1016/j.bcmd.2005.03.003

121. Clayton A, Mitchell JP, Court J, Linnane S, Mason MD, Tabi Z. Human tumor-derived exosomes down-modulate NKG2D expression. J Immunol. (2008) 180:7249-58. doi: 10.4049/jimmunol.180.11.7249

122. Ashiru O, Boutet $\mathrm{P}$, Fernandez-Messina L, Aguera-Gonzalez S, Skepper JN, Vales-Gomez M, et al. Natural killer cell cytotoxicity is suppressed by exposure to the human NKG2D ligand MICA*008 that is shed by tumor cells in exosomes. Cancer Res. (2010) 70:481-9. doi: 10.1158/0008-5472.CAN-09-1688

123. Hedlund M, Nagaeva O, Kargl D, Baranov V, Mincheva-Nilsson L. Thermaland oxidative stress causes enhanced release of NKG2D ligand-bearing immunosuppressive exosomes in leukemia/lymphoma T and B cells. PLoS ONE. (2011) 6:e16899. doi: 10.1371/journal.pone.0016899

124. Hua J, Inomata $\mathrm{T}$, Chen $\mathrm{Y}$, Foulsham W, Stevenson W, Shiang $\mathrm{T}$, et al. Pathological conversion of regulatory $\mathrm{T}$ cells is associated with loss of allotolerance. Sci Rep. (2018) 8:7059. doi: 10.1038/s41598-018-25384-x

125. Lei H, Schmidt-Bleek K, Dienelt A, Reinke P, Volk HD. Regulatory T cell-mediated anti-inflammatory effects promote successful tissue repair in both indirect and direct manners. Front Pharmacol. (2015) 6:184. doi: 10.3389/fphar.2015.00184

126. Sakaguchi S. Naturally arising CD4+ regulatory t cells for immunologic selftolerance and negative control of immune responses. Ann Rev Immunol. (2004) 22:531-62. doi: 10.1146/annurev.immunol.21.120601.141122

127. Grindebacke H, Stenstad H, Quiding-Jarbrink M, Waldenstrom J, Adlerberth I, Wold AE, et al. Dynamic development of homing receptor expression and memory cell differentiation of infant CD4+CD25high regulatory $\mathrm{T}$ cells. J Immunol. (2009) 183:4360-70. doi: 10.4049/jimmunol.0901091

128. Burzyn D, Kuswanto W, Kolodin D, Shadrach JL, Cerletti M, Jang Y, et al. A special population of regulatory $\mathrm{T}$ cells potentiates muscle repair. Cell. (2013) 155:1282-95. doi: 10.1016/j.cell.2013.10.054

129. Kursar M, Bonhagen K, Fensterle J, Kohler A, Hurwitz R, Kamradt T, et al. Regulatory CD4+CD25+ T cells restrict memory CD8+ T cell responses. $J$ Exp Med. (2002) 196:1585-92. doi: 10.1084/jem.20011347

130. Zhao DM, Thornton AM, DiPaolo RJ, Shevach EM. Activated CD4+CD25+ $\mathrm{T}$ cells selectively kill B lymphocytes. Blood. (2006) 107:3925-32. doi: 10.1182/blood-2005-11-4502

131. Trzonkowski P, Szmit E, Mysliwska J, Dobyszuk A, Mysliwski A. $\mathrm{CD} 4+\mathrm{CD} 25+\mathrm{T}$ regulatory cells inhibit cytotoxic activity of T CD8+ and NK lymphocytes in the direct cell-to-cell interaction. Clin Immunol. (2004) 112:258-67. doi: 10.1016/j.clim.2004.04.003

132. Misra N, Bayry J, Lacroix-Desmazes S, Kazatchkine MD, Kaveri SV. Cutting edge: human CD4+CD25+ T cells restrain the maturation and antigenpresenting function of dendritic cells. J Immunol. (2004) 172:4676-80. doi: 10.4049/jimmunol.172.8.4676

133. Taams LS, van Amelsfort JM, Tiemessen MM, Jacobs KM, de Jong EC, Akbar AN, et al. Modulation of monocyte/macrophage function by human CD4+CD25+ regulatory T cells. Hum Immunol. (2005) 66:222-30. doi: 10.1016/j.humimm.2004.12.006

134. Wang Y, Ma Y, Fang Y, Wu S, Liu L, Fu D, et al. Regulatory T cell: a protection for tumour cells. J Cell Mol Med. (2012) 16:425-36. doi: 10.1111/j.1582-4934.2011.01437.x 
135. Muller L, Simms P, Hong CS, Nishimura MI, Jackson EK, Watkins SC, et al. Human tumor-derived exosomes (TEX) regulate Treg functions via cell surface signaling rather than uptake mechanisms. Oncoimmunology. (2017) 6:e1261243. doi: 10.1080/2162402X.2016.1261243

136. Szajnik M, Czystowska M, Szczepanski MJ, Mandapathil M, Whiteside TL. Tumor-derived microvesicles induce, expand and up-regulate biological activities of human regulatory T cells (Treg). PLoS ONE. (2010) 5:e11469. doi: 10.1371/journal.pone.0011469

137. Huang B, Zhao J, Li H, He KL, Chen Y, Chen SH, et al. Toll-like receptors on tumor cells facilitate evasion of immune surveillance. Cancer Res. (2005) 65:5009-14. doi: 10.1158/0008-5472.CAN-05-0784

138. Kelly MG, Alvero AB, Chen R, Silasi DA, Abrahams VM, Chan $\mathrm{S}$, et al. TLR-4 signaling promotes tumor growth and paclitaxel chemoresistance in ovarian cancer. Cancer Res. (2006) 66:3859-68. doi: 10.1158/0008-5472.CAN-05-3948

139. Li D, Jia H, Zhang H, Lv M, Liu J, Zhang Y, et al. TLR4 signaling induces the release of microparticles by tumor cells that regulate inflammatory cytokine IL-6 of macrophages via microRNA let-7b. Oncoimmunology. (2012) 1:68793. doi: 10.4161/onci.19854

140. Chen X, Ying X, Wang X, Wu X, Zhu Q, Wang X. Exosomes derived from hypoxic epithelial ovarian cancer deliver microRNA-940 to induce macrophage M2 polarization. Oncol Rep. (2017) 38:522-8. doi: 10.3892/or.2017.5697

141. Ying $\mathrm{X}, \mathrm{Wu} \mathrm{Q}, \mathrm{Wu} \mathrm{X}, \mathrm{Zhu} \mathrm{Q}$, Wang $\mathrm{X}$, Jiang L, et al. Epithelial ovarian cancer-secreted exosomal miR-222-3p induces polarization of tumor-associated macrophages. Oncotarget. (2016) 7:43076-87. doi: 10.18632/oncotarget.9246

142. Yoshimura A, Naka T, Kubo M. SOCS proteins, cytokine signalling and immune regulation. Nat Rev Immunol. (2007) 7:454-65. doi: $10.1038 /$ nri2093

143. Arnold CE, Whyte CS, Gordon P, Barker RN, Rees AJ, Wilson HM. A critical role for suppressor of cytokine signalling 3 in promoting M1 macrophage activation and function in vitro and in vivo. Immunology. (2014) 141:96-110. doi: $10.1111 /$ imm. 12173

144. Liu Y, Stewart KN, Bishop E, Marek CJ, Kluth DC, Rees AJ, et al. Unique expression of suppressor of cytokine signaling 3 is essential for classical macrophage activation in rodents in vitro and in vivo. J Immunol. (2008) 180:6270-8. doi: 10.4049/jimmunol.180.9.6270

145. Soki FN, Koh AJ, Jones JD, Kim YW, Dai J, Keller ET, et al. Polarization of prostate cancer-associated macrophages is induced by milk fat globule-EGF factor 8 (MFG-E8)-mediated efferocytosis. J Biol Chem. (2014) 289:2456072. doi: 10.1074/jbc.M114.571620

146. Gabrusiewicz K, Li X, Wei J, Hashimoto Y, Marisetty AL, Ott M, et al. Glioblastoma stem cell-derived exosomes induce M2 macrophages and PDL1 expression on human monocytes. Oncoimmunology. (2018) 7:e1412909. doi: 10.1080/2162402X.2017.1412909

147. Cooks T, Pateras IS, Jenkins LM, Patel KM, Robles AI, Morris J, et al. Mutant p53 cancers reprogram macrophages to tumor supporting macrophages via exosomal miR-1246. Nat Commun. (2018) 9:771. doi: 10.1038/s41467-018-03224-w

148. Yang M, Chen J, Su F, Yu B, Su F, Lin L, et al. Microvesicles secreted by macrophages shuttle invasion-potentiating microRNAs into breast cancer cells. Mol Cancer. (2011) 10:117. doi: 10.1186/1476-4598-10-117
149. Bell BM, Kirk ID, Hiltbrunner S, Gabrielsson S, Bultema JJ. Designer exosomes as next-generation cancer immunotherapy. Nanomedicine. (2016) 12:163-9. doi: 10.1016/j.nano.2015.09.011

150. Morishita M, Takahashi Y, Matsumoto A, Nishikawa M, Takakura Y. Exosome-based tumor antigens-adjuvant co-delivery utilizing genetically engineered tumor cell-derived exosomes with immunostimulatory CpG DNA. Biomaterials. (2016) 111:55-65. doi: 10.1016/j.biomaterials.2016.09.031

151. Mahmoodzadeh Hosseini H, Imani Fooladi AA, Soleimanirad J, Nourani MR, Davaran S, Mahdavi M. Staphylococcal entorotoxin B anchored exosome induces apoptosis in negative esterogen receptor breast cancer cells. Tumour Biol. (2014) 35:3699-707. doi: 10.1007/s13277-013-1489-1

152. Cai X, Yin Y, Li N, Zhu D, Zhang J, Zhang CY, et al. Re-polarization of tumor-associated macrophages to pro-inflammatory M1 macrophages by microRNA-155. J Mol Cell Biol. (2012) 4:341-3. doi: 10.1093/jmcb/mjs044

153. Syn NL, Wang L, Chow EK, Lim CT, Goh BC. Exosomes in cancer nanomedicine and immunotherapy: prospects and challenges. Trends Biotechnol. (2017) 35:665-76. doi: 10.1016/j.tibtech.2017.03.004

154. Wozniak MB SG, Muller DC, Mukeria A, Zaridze D, Brennan P. Circulating microRNAs as non-invasive biomarkers for early detection of non-small-cell lung cancer. PLoS ONE. (2015) 10:e0125026. doi: 10.1371/journal.pone.0125026

155. Viaud S, Terme M, Flament C, Taieb J, Andre F, Novault S, et al. Dendritic cell-derived exosomes promote natural killer cell activation and proliferation: a role for NKG2D ligands and IL-15R $\alpha$. PLoS ONE. (2009) 4:e4942. doi: 10.1371/journal.pone.0004942

156. Escudier B, Dorval T, Chaput N, Andre F, Caby MP, Novault S, et al. Vaccination of metastatic melanoma patients with autologous dendritic cell (DC) derived-exosomes: results of thefirst phase I clinical trial. J Transl Med. (2005) 3:10. doi: 10.1186/1479-5876-3-10

157. Morse MA, Garst J, Osada T, Khan S, Hobeika A, Clay TM, et al. A phase I study of dexosome immunotherapy in patients with advanced non-small cell lung cancer. J Transl Med. (2005) 3:9. doi: 10.1186/1479-5876-3-9

158. Besse B, Charrier M, Lapierre V, Dansin E, Lantz O, Planchard D, et al. Dendritic cell-derived exosomes as maintenance immunotherapy after first line chemotherapy in NSCLC. Oncoimmunology. (2016) 5:e1071008. doi: 10.1080/2162402X.2015.1071008

159. Tran TH, Mattheolabakis G, Aldawsari H, Amiji M. Exosomes as nanocarriers for immunotherapy of cancer and inflammatory diseases. Clin Immunol. (2015) 160:46-58. doi: 10.1016/j.clim.2015.03.021

160. Batista IA, Melo SA. Exosomes and the Future of Immunotherapy in Pancreatic Cancer. Int J Mol Sci. (2019) 20:E567. doi: 10.3390/ijms20030567

Conflict of Interest Statement: The authors declare that the research was conducted in the absence of any commercial or financial relationships that could be construed as a potential conflict of interest.

Copyright $(\odot 2019$ Othman, Jamal and Abu. This is an open-access article distributed under the terms of the Creative Commons Attribution License (CC BY). The use, distribution or reproduction in other forums is permitted, provided the original author(s) and the copyright owner(s) are credited and that the original publication in this journal is cited, in accordance with accepted academic practice. No use, distribution or reproduction is permitted which does not comply with these terms. 